\title{
Experiences of improving water access in rural areas in Guatemala
}

\author{
Elena Bresci, Antonio Giacomini, Federico Preti \\ Dipartimento di Gestione dei Sistemi Agrari, Alimentari e Forestali (GESAAF), Sezione di \\ Ingegneria Agraria, Forestale e dei Biosistemi, Università di Firenze, Firenze, Italy
}

\begin{abstract}
The GESAAF Department of the UNIFI has been involved in the project "Gestione ambientale e del rischio nel dipartimento di Sololà" in the period 2011-'12 aiming at guaranteeing water access to people leaving in rural areas in the Sololà Department in Guatemala, in collaboration with the two NGOs Movimento Africa '70 and Oxfam Italia. Appropriate technologies, such as EMAS pump and well drilled with the BaptistaBoliviana technique, have been proposed and utilized for improving water access in areas where lack of water represented a limiting factor for the human development. They can be both considered compatible with local, cultural and economic conditions: in fact locally available materials are used and the tools can be maintained and operationally controlled by the local users. At the end of the project, 52 EMAS pumps have been installed and 19 wells drilled, 33 pumps have been installed in already existing wells tank. Formation activities of local people played an important role: diffusion actions of the methodology started from schools, 20 workers participated to an in class course and more than 100 participated in the field work. Monitoring activities on the 52 installed pumps have been carried out in order to check the performances of the pumps and the knowledge level acquired by the users. After some months of operation, more than $80 \%$ of the pumps were correctly functioning and the required maintenance activities have been carried out in collaboration with the local users. In order to analyze the project results, a SWOT analysis (Strengths, Weaknesses, Opportunities, and Threats) has been carried out for developing a strategy able to tackle the weaknesses and threats of the procedure. The application of the SWOT analysis showed to be an useful tool to analyse the current situation coming from the ended project. It has been helpful to gauge how the project performed. The analysis results may be also utilized for exploring strengths and weaknesses of a possible transferring of the methodology to other sites.
\end{abstract}

Correspondence: Prof. Elena Bresci, Università degli Studi di Firenze Dipartimento GESAAF, Via San Bonaventura 13, 50145 Firenze, Italy E.mail: elena.bresci@unifi.it

Key words: Bolivian Baptist well drilling technique, EMAS pump, SWOT analysis, improved water access.

(C) Copyright E. Bresci et al., 2013

Licensee PAGEPress, Italy

Journal of Agricultural Engineering 2013; XLIV(s2):e171

doi:10.4081/jae.2013.s2.e171

This article is distributed under the terms of the Creative Commons Attribution Noncommercial License (by-nc 3.0) which permits any noncommercial use, distribution, and reproduction in any medium, provided the original author(s) and source are credited.

\section{Introduction}

One of the World Health Organization (WHO) Millennium Development Goals has been established in cutting in half the proportion of people without access to safe drinking water and basic sanitation by 2015 (Sachs, 2005). WHO has declared 2005-2015 the decade of water, with the goal of establishing the framework to eventually provide full access to water supply and sanitation for all people. In order to achieve that goal, the increase of the percentage of residences in rural areas with household connections for drinking water has been set by WHO. In Guatemala, the percentage went from $34 \%$ of all households in 1990 to $53 \%$ in 2002 . Even the increase of that percentage, nearly half of Guatemala's inhabitants of undeveloped areas is obtaining drinking water of doubtful quality from nearby lakes or streams, cisterns, shallow wells, or spring-fed gravity-flow systems. Numerous health problems are still associated with contaminated water consumption, including amoebic dysentery, hepatitis and cholera (Martin and Elmore, 2007). In rural areas of Guatemala, although municipal governments are compelled by law to disinfect water, water treatment to guarantee safe drinking water is not routinely performed. Even though local users consider their water to be clean, it is generally thought by the scientific community as unsafe water in rural areas. Water sources in these areas consist of reservoirs fed by springs or wells and available water is frequently contaminated by both human and animal faeces (Lopez et al., 2003). Disinfecting water by boiling at home, before drinking, is the most common and utilized household water treatment. But without a safe storage, boiled water can be immediately vulnerable to recontamination (Rosa et al., 2010). The WHO (2000) individuated the availability of clean water for drinking as an important concern in developing countries, particularly in Latin America (Elmore and Fahrenholtz, 2007). The access to safe water became more difficult after the 2010 tropical storm, Agatha, made landfall on the Pacific coast of Guatemala on May 29. It resulted in more than $426 \mathrm{~mm}$ of rain in a short period of time. Flooding caused extensive damage across a large part of the country. Simultaneously, an eruption of Pacaya Volcano limited search and rescue operations as well as the provision of humanitarian relief. Communities lost homes or had their homes damaged. The loss of crops and livelihoods risks increasing food insecurity. People then lack food and clean drinking water. In 2011, the Department of Agricultural, Food and Forestry Systems (GESAAF) of the University of Florence (UNIFI) has been involved in the project "Gestione ambientale e del rischio nel dipartimento di Sololà" aiming at guaranteeing water access to people leaving in rural areas in the Sololà Department in Guatemala, in collaboration with the two NGOs, Movimento Africa '70 and Oxfam Italia. The use of appropriate technologies has been tested on the field, EMAS (Escuela Móvil del Agua y Saneamiento, http://paulcloesen.50webs.com/ DocEMAS/SistemasEMAS.pps\#256,1,Sistemas de Agua EMAS) pump and drilling well with the Baptista-Boliviana technique, have been proposed and utilized for improving water access in areas where lack of water is representing a limiting factor for the human development (Petrone et al., 2009). The term improved water access is used accord- 
ing to the definition proposed by Montgomery et al., (2007), representing households that obtain water from sources that are superior to traditional, unprotected ones. Strengths, weakness, opportunities and threats (SWOT) analysis has been applied in order to analyze the project results, and developing a strategy able to tackle the weaknesses and threats of the procedure. Based on that, modifications will be applied before transferring the methodology to some other rural areas both in Guatemala and in some other countries, characterized by similarity in the difficulty of water access.

\section{Materials and methods}

\section{Study area}

The study is conducted over a period of two years (2011-2012) in the Municipality of Sololà, Department of Sololà, in Guatemala (Figure 1). The Department covers an area of $1061 \mathrm{~km}^{2}$, representing the $9 \%$ of the VI Region, made up of other five departments: Totonicapán, Quetzalenango, San Marcos, Suchitepéquez and Retalhuleu. In 2008, the population of the Department was of about 398000 people $(49 \%$ male and $51 \%$ female). More than $96 \%$ of the population belongs to the Mayan ethnicities: Tzutujiles, Quichés and Kakchiqueles. Its main subsistence is agriculture with a minority relying in industry and commercial activities. Literacy is $50 \%$ and, in some areas, reaches only the $10 \%$. An estimated $77 \%$ of the population in the Department is classified as poor and 18\% as extreme poor. In these rural communities, it has been estimated that more than $40 \%$ of the families does not have permanent access to water, and the situation became worst after the hurricane Agatha. In fact, the most common water resource, spring water, has not been any more available after the hurricane for both quantity and quality reasons.

\section{The project Gestione ambientale e del rischio nel dipartimento di Sololà}

The Department of Agricultural, Food and Forestry Systems (GESAAF) of the University of Florence (UNIFI) has been involved in the project "Gestione ambientale e del rischio nel dipartimento di Sololà" in the period 2011-'12 aiming at improving life conditions of people, leaving in rural areas in the Sololà Department in Guatemala,

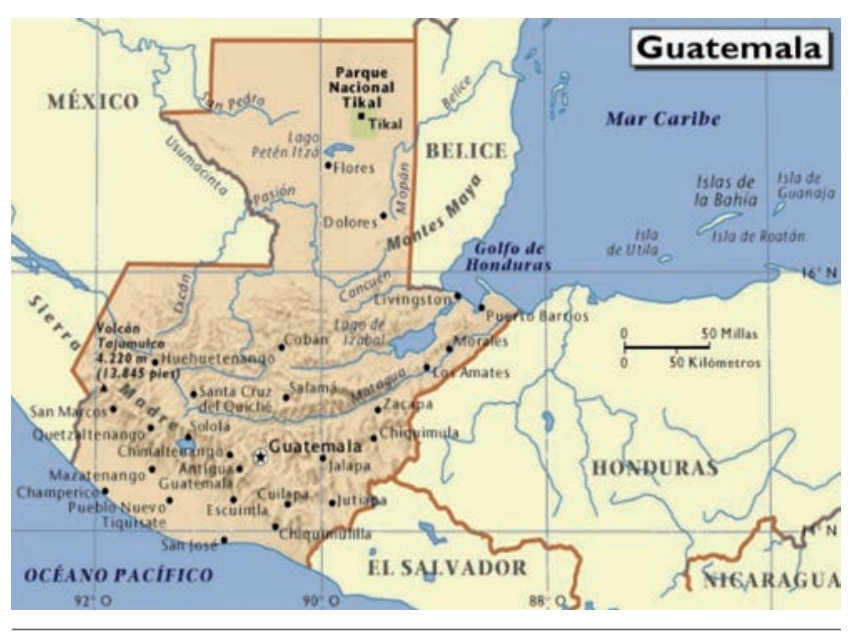

Figure 1. The study area. in collaboration with the two Italian NG0s, Movimento Africa '70 and Oxfam Italia (funded also by Tuscany Region and Italian Ministry of Education and Research, Cooperation funds). In particular, the GESAAF focused the attention on improving water access to families living in rural areas, providing a safe and reliable source of water, applying the participatory approach and using appropriate technologies.

Participatory approach, in the bottom up form, involved beneficiaries starting from scratch, through the analysis of the information given from the interactive participation (Pimbert and Pretty, 1994). Surveys carried out on the field, through questionnaires and interviews to people in rural areas in the Sololà Department, showed water access as a priority to favouring the human development in that area. Appropriate technologies, such as the EMAS (Escuela Móvil del Agua y Saneamiento) pump and the Bolivian Baptista well drilling technique

(http://www.waterforallinternational.org/Documents/WFA\%20Bolivia $\mathrm{n} \% 20$ Baptist\%20Drilling\%20System.pps), have been proposed and utilized for improving water access in areas where lack of water represented a limiting factor for the human expansion. They can be both considered compatible with local, cultural and economic conditions: in fact, locally available materials are used and the tools can be maintained and operationally controlled by the local users, once trained. Many local associations have been involved in the project to ensure the local participation: Asociacíon Amigos del Lago (AALA), Asociacíon para el Mejoramiento Habitacional de Guatemala (MEJORHA), Oficina Municipal de Agua de Sololà, Oficina Municipal Indígena de Sololà, Oficina Municipal de Agua (OMA).

The individuation of sites for well drilling has been carried out through the interactive participation of local people in joint analysis, to strengthen the role of local institutions. In fact, interdisciplinary methodologies, seeking multiple objectives (social, medical, sanitary, etc.) have been tested. In such a way, local groups may have control on the decisions and in the long term, will have a stake in maintaining operational the structures (well and pump). Some criteria considered for well drilling localization were represented by: water table depth according to local people information, soil type, family priorities (number of children, income, number of women), number of family utilizing the same well, collaboration offered by the families in well drilling, collaboration offered by people of the community in the case of collective well drilling (school, public sites, etc.). Formation activities of local people played an important role: diffusion actions of the methodology started from schools, 20 workers participated to an in class course and more than 100 participated in the field work.

The well drilling and EMAS pump construction (Figure 2a) have been carried out by trained on the field workers, some of them were the owner of the well and some other were simple workers that have learned or where learning the technique. In fact, it happened that people working for a well became the responsible for the training in a nearby well. The OMA engaged itself to provide water quality analysis for each location of pump installed. Accuracy has been paid on well protection by contamination from the surface, but obviously, nothing could be made on the original quality of the water. Monitoring activities on the 52 installed pumps have been carried out in order to check the performances of the pumps (Figure 2b) and the acquired knowledge level by the users. More than $70 \%$ of the pumps were correctly functioning and the required maintenance activities have been carried out in collaboration with the local users.

\section{The SWOT analysis}

Strengths, Weakness, Opportunities and Threats (SWOT) approach involves thinking and diagnosis of factors related to a new product, technology, management or planning (Weihrich, 1982). It is considered a common and useful tool in strategic planning, where all factors influ- 


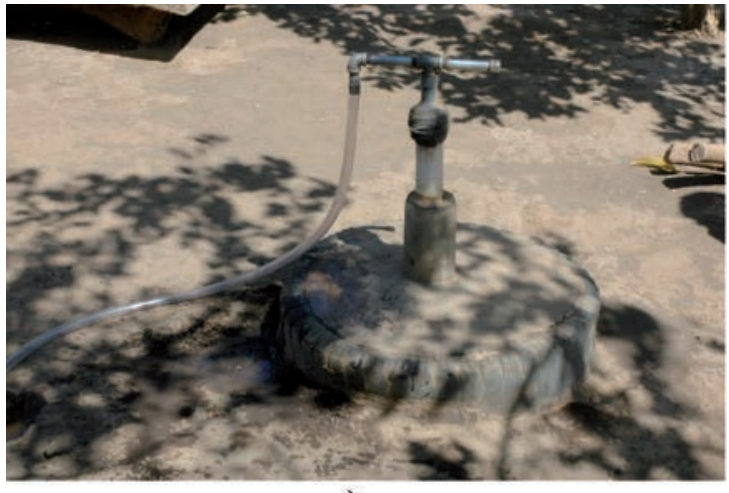

a)

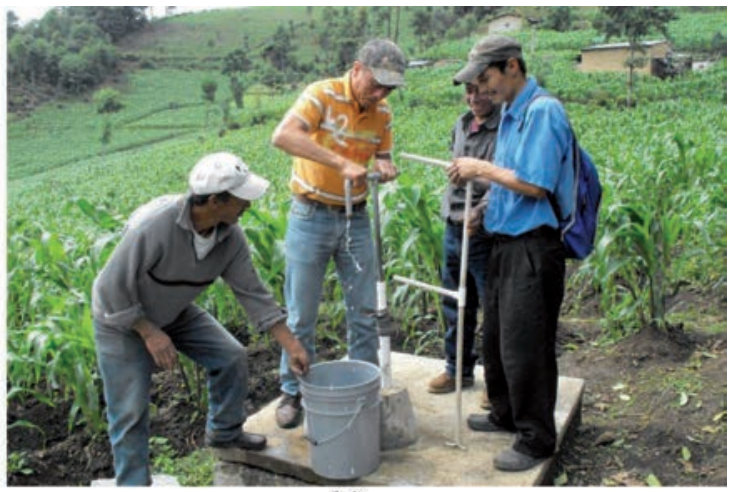

b)

Figure 2. a) The EMAS pump in a drilled well. 2b) Performing analysis on the EMAS pump in an existing well tank.

encing the operational environment are diagnosed with greater details (Kotler, 1994; Smith, 1999; Hill and Westbrook, 1997). In particular, it allows analysts to classify factors into internal (strengths, weaknesses) and external (opportunities, threats) as they relate to a decision and thus enables them to compare opportunities and threats with strengths and weaknesses. One of the main limitation of the approach is that the importance and the value of each factor cannot be measured quantitatively. It appears clear, then, that it is difficult to assess which is the factor influencing the strategic decision most (Pesonen et al., 2000).

The actions to be undertaken deduced from the matrix analysis are represented by: build on strengths; eliminate weaknesses; exploit opportunities; mitigate the effect of threats.

\section{Results}

At the end of the project, 52 EMAS pumps have been installed and 19 wells drilled, 33 pumps have been installed in already existing wells tank. The main characteristics of the two situations are presented, respectively, in Table 1 and 2.

As regards, the well drilling, the Baptista Bolivian technique seemed to be adequate to the local situation, only in two cases out of 19 , it has been necessary the abandonment of the original site of drilling, due to the presence of a rock stratum. In all the other cases, there were mainly sandy strata. This is the reason why the numbers go from 1 to 21 . The mean value of the well depth is $4.8 \mathrm{~m}$ (with a standard deviation of 2.09 $\mathrm{m}$ ) below the water level. The mean values of the number of days needed for the drilling is around 13 (with a standard deviation of 5), and obviously it depends on the strataum type found in the aquifer. When rock is present it takes much longer.

33 EMAS pumps have been located in existing wells of the tank type. The number of days, variable from 1 to 3 , have been necessary for the pump construction, generally one day, and for realizing the cement structure for closing the well, once the pump have been installed. In fact, attention have to be put on avoiding contamination on the well water. As we can see from Table 2, the water level in the existing wells is much closer to the topographic surface (mean value of $2.7 \mathrm{~m}$ with a standard deviation of $2.1 \mathrm{~m}$ ) than in the case of drilled wells. The mean value of work days is 2.6 (with a standard deviation of 0.68 ). All the existing wells were belonging to families; that's why the new drilled wells have been located in area where the use could be collective. Water was previously withdrawn with a pail and the well was opened, subjected to contamination from the above. The utilization of the hand pump and the possibility of closing the well to avoiding contamination made users very pleased with proposed tools.

The monitoring phase has been carried out in the month of June 2012 , after 2-3 months of pump operation. All the 52 pumps have been tested to verify their performances. The $85 \%$ of the pumps (44 out of $52)$ were functioning. The water volume extracted in the unit time (1 minute) has been compared with the ideal value, taken as $15 \mathrm{l} / \mathrm{min}$

Table 1. Drilled wells with the Baptista Bolivian technique and EMAS pump positioning.

\begin{tabular}{|c|c|c|c|c|c|c|}
\hline N. & Well location & Acce & pe* & $\begin{array}{r}\text { Dep } \\
\text { [n }\end{array}$ & & $\begin{array}{l}\text { Work } \\
\text { days }\end{array}$ \\
\hline & & D & $\mathrm{C}$ & Water & Well & \\
\hline 1 & Escuela Central Chuiquel & & $\times$ & 10.5 & 16 & 24 \\
\hline 2 & Aldea San Juan Argueta & & $x$ & 3 & 11 & 11 \\
\hline 3 & Escuela Central Xajaxac & & $x$ & 2.5 & 4.3 & 23 \\
\hline 4 & Escuela Central Los Encuentros & & $\times$ & 17 & 23 & 11 \\
\hline 5 & Central Los Encuentros & $x$ & & 15 & 22 & 6 \\
\hline 6 & Cantón Chiuel & $x$ & & 20 & 24.5 & 25 \\
\hline 7 & Escuela Nueva Amanecer & & $\times$ & 20.5 & 26 & 15 \\
\hline 8 & Cantón Xajaxac & $x$ & & 8.5 & 12 & 13 \\
\hline 9 & Sector Nueva Amanecer & $x$ & & 25 & 29 & 8 \\
\hline 10 & Escuela San Francisco & & $x$ & 15.5 & 20.30 & 12 \\
\hline 12 & Escuela El Ascenso & & $\times$ & 16.5 & 21.8 & 17 \\
\hline 13 & Central Los Encuentros & $x$ & & 12 & 23.85 & 8 \\
\hline 14 & Central Los Encuentros & $x$ & & 24 & 28.3 & 10 \\
\hline 16 & Caserío San Francisco & $x$ & & 16 & 21 & 9 \\
\hline 17 & Escuela Pacoxom & & $\times$ & 3.5 & 7.85 & 14 \\
\hline 18 & Escuela El Encanto & & $x$ & 16 & 20.2 & 9 \\
\hline 19 & Caserío Chujulimul & & $x$ & 17.5 & 23 & 10 \\
\hline 20 & Caserío El Rosario & & $x$ & 25.5 & 29.3 & 9 \\
\hline 21 & Caserío El Paraíso & $x$ & & 22 & 25.8 & 17 \\
\hline
\end{tabular}


Table 2. EMAS pumps in existing well tanks.

\begin{tabular}{|c|c|c|c|c|}
\hline \multirow[t]{2}{*}{ N. Well and pump location } & Access type* & \multicolumn{2}{|c|}{$\begin{array}{l}\text { Depth } \\
\text { [m] }\end{array}$} & \multirow[t]{2}{*}{$\begin{array}{l}\text { Work } \\
\text { days }\end{array}$} \\
\hline & C & Water & Well & \\
\hline 1 Cantón Xajaxac & $x$ & 2.80 & 4.35 & 3 \\
\hline 2 Cantón Хaјaxac & $x$ & 1.50 & 2.65 & 5 \\
\hline 3 Cantón Хajaxac & $\times$ & 13.40 & 15.80 & 4 \\
\hline 4 Sector Nueva Amanecer & $\times$ & 1.70 & 8.20 & 2 \\
\hline 5 Sector Nueva Amanecer & $x$ & 3.60 & 12.90 & 2 \\
\hline 6 Cantón Chiuel & $\times$ & 3.25 & 10.10 & 2 \\
\hline 7 Sector Nueva Amanecer & $\times$ & 2.10 & 10.30 & 2 \\
\hline 8 Sector Nueva Amanecer & $\times$ & 1.90 & 9.80 & 2 \\
\hline 9 Aldea Los Encuentros & $\times$ & 2.90 & 10.20 & 2 \\
\hline 10 Sector Nueva Amanecer & $\times$ & 1.90 & 7.80 & 2 \\
\hline 11 Aldea Los Encuentros & $\times$ & 3.90 & 15.30 & 2 \\
\hline 12 Aldea Los Encuentros & $x$ & 2.20 & 9.90 & 2 \\
\hline 13 Aldea Los Encuentros & $x$ & 2.10 & 6.20 & 2 \\
\hline 14 Aldea Los Encuentros & $x$ & 1.90 & 6.10 & 2 \\
\hline 15 Caserío San Francisco & $\times$ & 1.90 & 8.40 & 2 \\
\hline 16 Caserío San Francisco & $\times$ & 2.60 & 7.80 & 3 \\
\hline 17 Caserío El Rosario & $\times$ & 2.10 & 9.50 & 3 \\
\hline 18 Caserío El Rosario & $\times$ & 2.00 & 7.10 & 2 \\
\hline 19 Caserío El Rosario & $x$ & 1.90 & 8.40 & 2 \\
\hline 20 Caserío Vista Hermosa & $\times$ & 0.90 & 23.20 & 2 \\
\hline 21 Caserío Vista Hermosa & $\times$ & 1.68 & 12.50 & 2 \\
\hline 22 Caserío Paxocon & $\times$ & 2.60 & 17.50 & 3 \\
\hline 23 Caserío Chujulimul & $\times$ & 1.60 & 14.50 & 2 \\
\hline 24 Caserío Chujulimul & $\times$ & 2.60 & 8.00 & 2 \\
\hline 25 Caserío Paxocon & $x$ & 2.10 & 4.65 & 3 \\
\hline 26 Caserío Valle del Norte & $\times$ & 1.50 & 16.10 & 2 \\
\hline 27 Caserío Valle del Norte & $\times$ & 2.40 & 8.90 & 2 \\
\hline 28 Caserío Valle del Norte & $x$ & 5.50 & 12.00 & 2 \\
\hline 29 Caserío Valle del Norte & $x$ & 2.10 & 10.60 & 2 \\
\hline 30 Caserío La Fé & $x$ & 2.40 & 16.80 & 2 \\
\hline 31 Caserío La Fé & $x$ & 1.90 & 9.40 & 2 \\
\hline 32 Caserío Central & $x$ & 2.00 & 4.10 & 2 \\
\hline 33 Caserío Chuiquel & $x$ & 2.30 & 11.20 & 2 \\
\hline
\end{tabular}

Table 3. The SWOT matrix.

\begin{tabular}{|c|c|}
\hline Internal & External \\
\hline $\begin{array}{l}\text { Strengths } \\
\text { - Availability of pump material construction } \\
\text { on the local market } \\
\text { - Easily repaired } \\
\text { - Hand operated (men, women, children) } \\
\text { - Low cost of the EMAS pump } \\
\text { - Pumping up to } 40 \text { m depth } \\
\text { - Water can be pumped directly into an } \\
\text { elevated storage tank }\end{array}$ & $\begin{array}{l}\text { Opportunities } \\
\text { - Improved water access } \\
\text { - Access to water of a better quality } \\
\text { - Partnership with other } \\
\text { communities for system } \\
\text { implementation } \\
\text { and pump construction }\end{array}$ \\
\hline $\begin{array}{l}\text { Weaknesses } \\
\text { - Lack of interest in recognizing low pump } \\
\text { performance from the users } \\
\text { - Testing of acquired competence } \\
\text { - Differences in time needed for pump } \\
\text { installation }\end{array}$ & $\begin{array}{l}\text { Threats } \\
\text { - Lack of hydrogeological map } \\
\text { - Difficulties in well drilling in } \\
\text { presence of rocks } \\
\text { - Groundwater quality concerns }\end{array}$ \\
\hline
\end{tabular}

(pump mobile part excursion equal to $45 \mathrm{~cm}$ and 50 pumping per minute). $26 \%$ of the pumps (5 out of 19 ) had a performance mean value of $90 \%$ (with a standard deviation of $7 \%$ ), for the $73 \%$ of the pumps there were problems in the wells for producing water both in terms of quantity (42\%) and quality (32\%) due to the presence of too much sediments. Then, activities related to improving well water production, has been carried out and, afterwards, the analysis of the produced water volume. The performance of the pumps, located in the existing wells, showed a mean value of $93 \%$ (with a standard deviation of $7 \%$ ). It appears clear that problems of water production were mainly depending on the well drilling.

In order to analyze the project results, a SWOT analysis (Strengths, Weaknesses, Opportunities, and Threats) has been carried out for developing a strategy able to tackle the weaknesses and threats of the proposed model. The internal system is represented by the use of the EMAS pump and the Baptista Bolivian technique for well drilling, the external system is the environment.

In Table 3 the SWOT matrix is presented.

\section{Conclusions}

In the framework of the project "Gestione ambientale e del rischio nel dipartimento di Sololà" (2011-'12) the GESAAF Department of the University of Florence (UNIFI) tested the utilization of appropriate technologies, the EMAS pump and the well drilling Baptista-Boliviana technique, for improving water access to people leaving in rural areas in the Sololà Department in Guatemala, in collaboration with the two NG0s, Movimento Africa ' 70 and Oxfam Italia. A total of 52 pumps have been installed, respectively, 19 in drilled wells and 32 in existing wells tank. More than 100 workers contributed to field activities and more than 250 people have been provided with groundwater. The application of the SWOT analysis showed to be an useful tool to analyse the current situation in terms of internal strength. The matrix analysis may be also explored for eliminating internal weaknesses and work on the exploitation of the external opportunities and mitigating the effect of external threats. Based on that analysis, the possible transferring of the methodology to other sites would be characterized by less uncertainty.

\section{References}

Ballestero M., Reyes V., Astorga Y. 2007. Groundwater in central America: its importance, development and use, with particular reference to its role in irrigated agriculture. In Giordano M., Villholth K.G., 2007. The Agricultural Groundwater Revolution: Opportunities and Threats to development. CAB International, IWMI.

Danca A. 2000. An explanation of the SWOT analysis process. http://www.stfrancis.edu/ba/ghkickul/stuwebs/btopics/works/swot.h tm

Elmore A.C., Fahrenholtz W.G., 2007. Using Science, Engineering and Education to Address Water Supply Challenges in the Highlands of Guatemala. World Environmental and water Resources Congress 2007: Restoring our Natural habitat.

González-Gómez F., Guardiola J., Lendechy Grajales A. 2011. The challenges of water access in Yucatán, México. Proceedings of the ICE - Municipal Engineer,Volume 164, Issue 1, 01 March 2011,45-53.

Hill T., Westbrook, R. 1997. SWOT analysis: it's time for a product recall. Long Range Planning 30(1):46-52.

http://www.waterforallinternational.org/Documents/WFA\%20Bolivian\% 20Baptist\%20Drilling\%20System.pps. 
http://paulcloesen.50webs.com/DocEMAS/SistemasEMAS.pps\#256,1,Sis temas de Agua EMAS.

Karppi I., Kokkonen M., Lähteenmäki-Smith K., 2001. SWOT analysis as a basis for regional strategies. Nordregio Working Paper 2001:4, ISSN 1403-2511.

Kotler P., 1994. Marketing Management: Analysis, Planning, Implementation and Control, $8^{\text {th }}$ Edition Printice-Hall, Englewood Cliffs, NJ.

Lopez B., Alvarez M., Mendoza C., Gerba C., Naranjo J., Luby S., Klein R. 2003. Quality of Source Water in A Rural Area of Guatemala. Epidemiology, Vol. 14, Issue 5.

Martin J.H., Elmore A.C. 2007. Water drinking attitudes and behaviours in Guatemala: an assessment and intervention. Journal of Rural and Tropical Health. 6:54-60.

Montgomery M.A., Elimelech M., 2007. Water and sanitation in developing countries: including health in the equation. Environmental Science and Technology, 17-24.

Pesonen M., Kurttila M., Kangas J., Kajanus M., Heinonen P. 2000. Assessing the priorities using A'WOT among resource management strategies at the Finish Forest and Park Service. Forest Science 47(4), 534-541.

Petrone A., Giacomin A., Preti, F. 2009. Sistemi appropriati e sostenibili per l'uso di risorse idriche da parte di comunità rurali: monitorag- gio e sperimentazioni. IX Convegno Nazionale dell'Associazione Italiana di Ingegneria Agraria, Ischia Porto, 12-16 settembre 2009, memoria n. 977.

Pimbert M. Pretty J. 1994. Parks, People and Professionals: Putting "Participation" into Protected Area Management. Discussion Paper No. 57. Geneva: UNRISD.

Rosa G., Miller L., Clasen T. 2010. Microbiological effectiveness of disinfecting water by boiling in rural Guatemala. Am. J. Trop. Med. Hyg., 82(3):473-477.

Sachs J.D. 2005. Investing in Development: A Practical Plan To Achieve the Millennium Development Goals; UN Development Programme: New York.

Smith J.A. 1999. The behaviour and performance of young micro firms: evidence from businesses in Scotland. Small Business economics 13:185-200.

Weihrich H. 1982. The TOWS matrix - a tool for situation analysis. Long Range Planning 15(2), 54-66.

Wickramasinghe V., Takano S. 2009. Application of a Combined SWOT and Analysis Hierarchy Process (AHP) for Tourism Revival Strategic Marketing Planning: a case of Sri Lanka Tourism. Journal of the Eastern Asia Society for Transportation Studies, Vol. 8.

World Health Organization (WHO) 2000. Global water supply and sanitation report 2000. UNICEF, New York. 